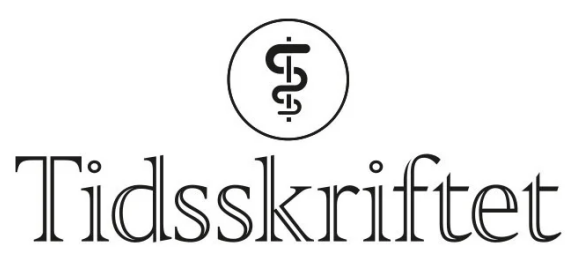

DEN NORSKE LEGEFORENING

\title{
Metabolsk og kardiovaskulær helse ved psykiske lidelser
}

NOE Å LARE AV

KÅRE I. BIRKELAND

Email: k.i.birkeland@medisin.uio.no

Oslo universitetssykehus, Aker

og

Det medisinske fakultet

Universitetet i Oslo

0514 Oslo

Det er anslått at personer med alvorlige psykiske lidelser som schizofreni og bipolar lidelse i gjennomsnitt har 25 år kortere forventet levetid enn referansebefolkningen (1). Den viktigste årsaken til denne overdødeligheten er hjerte- og karsykdommer - ikke selvmord. Denne $ø$ kte risikoen har mange årsaker, blant andre knyttet til lav sosioøkonomisk status, uheldige levevaner og underbehandling av somatisk sykdom og risikofaktorer hos psykiatriske pasienter. 50-80 \% av dem med alvorlig psykiatrisk sykdom røyker, og det er

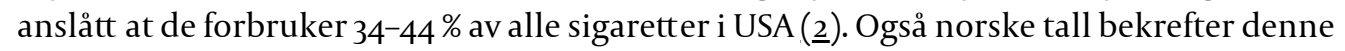
tendensen: Forekomsten av kardiovaskulære risikofaktorer som røyking, hypertensjon, fedme, diabetes og dyslipidemi var omtrent dobbelt så høy hos dem med alvorlige psykiske sykdommer som i den generelle befolkningen (3). Personer med alvorlig psykisk sykdom ser ut til å ha en sykdomsassosiert sårbarhet som utsetter dem for betydelig risiko når de eksponeres for det moderne fedmefremmende (obesogene) miljø.

Selv om det er holdepunkter for å anta at de fleste nevroleptika kan medvirke til vektøkning, ser det ut til at klozapin og olanzapin har størst slik effekt. Mekanismene for denne vektøkningen er ikke fullt ut kartlagt, men trolig er en direkte appetittstimulerende virkning via stimulering av $\mathrm{H}_{1}$-histaminreseptor viktig (4). Det kan passe med at de medikamentene som har sterk affinitet til $\mathrm{H}_{1}$-reseptoren, er de der dette er mest aktuelt. I tillegg til, og delvis som en følge av vektøkningen, forverres ofte risikofaktorer for metabolsk syndrom, type 2-diabetes og aterosklerotisk hjerte- og karsykdom hos personer med alvorlige psykisk sykdom.

I flere studier har man funnet at forekomsten av metabolsk syndrom og type 2-diabetes er $\emptyset \mathrm{kt}$ 2-4 ganger hos personer med schizofreni. Og pasienter med psykisk sykdom har gjennomgående dårligere diabetesregulering enn andre. Det kan ha sammenheng med faktorer knyttet til pasienten (kommunikasjonsvansker, vansker med oppfølging av behandlingsopplegg) eller til helsevesenet (for liten tid til «vanskelige pasienter», prioritering av den for øyeblikket mest alvorlige tilstand). I en studie fra USA var 
mangelfull måloppnåelse for diabetesbehandlingen betydelig hyppigere hos pasienter som også hadde en psykiatrisk diagnose (5). Det gjaldt både for prosessmål (andel som fikk målt $\mathrm{HbA}_{1 \mathrm{C}}$ eller LDL-kolesterol) og for resultatmål (andel med dårlig blodsukkerkontroll eller for høyt kolesterolnivå). Selv om man de siste årene i økende grad er blitt klar over viktigheten av å følge opp kardiovaskulære og metabolske risikofaktorer hos pasienter med psykisk sykdom som bruker annengenerasjonsantipsykotika, måles fortsatt blodglukose og lipider for sjelden hos disse (므). Som et ledd i å ta seg bedre av den somatiske helsen til pasienter med alvorlig psykisk sykdom er det derfor en viktig påminning Sæverud \& Gerlyng gir i sin kasuistikk.

\section{Oppgitte interessekonflikter:}

Ingen

\section{LITTERATUR}

1. Colton CW, Manderscheid RW. Congruencies in increased mortality rates, years of potential life lost, and causes of death among public mental health clients in eight states. Prev Chronic Dis 2006; 3 : A42.

2. Newcomer JW, Hennekens $\mathrm{CH}$. Severe mental illness and risk of cardiovascular disease. JAMA 2007; 298: $1794-6$.

3. Birkenaes AB, Søgaard AJ, Engh JA et al. Socio-demographic characteristics and cardiovascular risk factors in patients with severe mental disorders compared with the general population. J Clin Psychiatry 2006; 67: 425-33.

4. Kroeze WK, Hufeisen SJ, Popadak BA et al. H1-histamine receptor affinity predicts short-term weight gain for typical and atypical antipsychotic drugs. Neuropsychopharmacology 2003; 28: 519-26.

5. Frayne SM, Halanych JH, Miller DR et al. Disparities in diabetes care. Impact of mental illness. Arch Int Med 2005; 165: 2631-8.

6. Morrato EH, Newcomer JW, Kamat S et al. Metabolic screening after the American Diabetes Associations's consensus statement on antipsychotic drugs and diabetes. Diabetes Care 2009; 32: 103742.

Publisert: 11. februar 2010. Tidsskr Nor Legeforen. DOI: 10.4045/tidsskr.09.1194

Manuskriptet ble mottatt 5.10. 2009 og godkjent 15.10. 2009. Medisinsk redaktør Odd Terje Brustugun. (C) Tidsskrift for Den norske legeforening 2023. Lastet ned fra tidsskriftet.no 26. april 2023. 